\title{
Analysis of Effect of learning Style on Mathematics Learning Outcomes
}

\author{
$1^{\text {st }}$ Markus Palobo* \\ Department of Mathematics Education \\ Universitas Musamus \\ Merauke, Indonesia \\ markuspalobo@unmus.ac.id
}

\author{
$2^{\text {st }}$ Sadrack Luden Pagiling \\ Department of Mathematics Education \\ Universitas Musamus \\ Merauke, Indonesia \\ pagiling@unmus.ac.id
}

\author{
$3^{\text {st }}$ Khumaeroh Dwi Nur'aini \\ Department of Mathematics Education \\ Universitas Musamus \\ Merauke, Indonesia \\ khumaeroh_fkip@unmus.ac.id
}

\begin{abstract}
This research is an ex post facto study which aims to find out what learning styles students have and whether there is influence of learning styles on students' mathematics learning outcomes. The population in this study was all students in SMP Negeri Urumb Merauke. Data analysis used descriptive statistics to describe the types of student learning styles and correlation coefficient inferential statistics of Eta test to determine whether there is the influence of learning styles on students' mathematics learning outcomes. The results obtained are students in SMP Negeri Urumb have diverse learning styles, those are $\mathbf{2 4 . 4 9 \%}$ of visual learning style, $53.06 \%$ of auditory learning style, and $22.45 \%$ of kinesthetic learning style. Analysis using Eta test obtained is influence of learning styles on mathematics learning outcomes.
\end{abstract}

Keywords: component, formatting, style, styling

\section{INTRODUCTION}

History has shown that humans on this earth with their limitations always try to find and find something new [1], this then encourages someone to do various ways to continue to obtain the information or knowledge needed, one of them by learning. In accordance with the opinion of Bell-Gredler that learning is a process carried out by humans to get a variety of abilities, skills and attitudes [2]. Cronbach adds that learning the best is to experience, and in the process of experiencing it one uses the senses [3]. In the process of learning individual differences include intelligence, talent, learning style, physical state, social and emotional adjustment, and learning outcomes. There are two main categories of how students learn. First, how students absorb information easily (learning styles) and second, how students organize and process that information (brain dominance) [4]. However, it is often found that student learning outcomes are low because teachers still do not use media in learning [5].

According to Rita Dunn there are three ways in which students absorb information, namely (a) visual learning style, (b) auditory learning style, and (c) kinesthetic learning style [6]. Students with visual learning learning styles through what is seen, students with auditory learning styles learn by listening, and students with kinesthetic learning styles learn through motion or touch. Some behavioral traits that are indicative of the tendency of student learning styles, including by understanding the typical words and speed of speech, also through verbal cues that are often given by students [4]. Students with a visual learning style understand something with visual associations, look neat and orderly, understand well about position, shape, numbers, and colors, and have difficulty receiving verbal instructions (verbal commands). Students with auditory learning styles have weak characteristics of visual activity, have sensitivity to music, and are good at oral activities. Students with kinesthetic learning styles learn through physical activity, are sensitive to body language, and like trial and error [7].

For processing and processing information (brain dominance), according to Anthony Gregorc there are four combinations of behavioral groups called thinking styles namely concrete sequential, sequential abstract, concrete random, and abstract random. People who fall into two "sequential" categories tend to have dominance of the left brain, while people who think randomly are usually included in the dominance of the right brain [4]. The right brain deals with rhythm, rhyme, music, images and imagination (creative activity) so that students with normal right brain dominance have an auditory or kinesthetic learning style. While the left brain plays a role in processing logic, words, mathematics and sequences (academic learning), students with left-brain dominance tend to have a visual learning style [8].

Mathematics is one of the most important lessons, especially in the development of science and technology [9]. In academic learning mathematics has an important role, acknowledged who wrote "It would be very difficult or impossible for someone to live in this part of the earth in the 20th century without taking the slightest advantage of mathematics [10]. Mathematics itself is a science that discusses patterns and order [11]. In the academic learning process, especially mathematics learning, the quality of learning can be seen in terms of the learning process and learning outcomes [12]. Learning outcomes are abilities possessed by students after receiving learning experiences. In the national education system the formulation of educational goals uses the classification of learning outcomes from Benjamin Bloom, namely the cognitive domain with respect to intellectual learning outcomes, affective domain with regard to attitudes, and psychomotor domains with regard to learning outcomes of skills and abilities [13].

Student learning outcomes are influenced by student background (IQ, learning style, etc.), infrastructure, and 
learning (good design, interesting presentation and fair evaluation) [14], agree with there are several factors that influence learning outcomes including learning styles and learning approaches [15]. The results of interviews with mathematics subject teachers at one of SMP Negeri Urumb, Merauke, Papua, Indonesian. Differences in student mathematics learning outcomes, namely high or low acquisition of assignment scores, daily tests, and semester tests are influenced by student learning styles. When the teaching and learning process takes place each student uses various ways to strengthen his understanding of the material delivered by the teacher, some students ask friends or teachers to re-explain the material, some students make notes or summaries, and other students strengthen their understanding by trying to solve the sample questions. The teacher also said that some students were easier to learn in groups and some students were easier to learn individually. That is, the acquisition of individual and group learning outcomes will be different for each student, depending on the tendency of the learning style possessed.

Based on the description above, the researchers conducted a study to determine the relationship between learning styles and mathematics learning outcomes of students at SMP Negeri Urumb with the title Analysis of the Effect of Learning Styles on Mathematics Learning Outcomes.

\section{RESEARCH METHODS}

This study included the type of ex post facto research, in this study not given treatment to the object of research, the approach used was a quantitative approach. Data analysis using descriptive statistics to describe the types of student learning styles and inferential statistics Eta test correlation coefficients are used to determine whether or not the influence of learning styles on student mathematics learning outcomes. In this study the learning style in question is a visual, auditorial, and kinesteric learning style.

Image samples used are images that have different levels of intensity change (images with steep edges, ramps, and images with edges containing noise). The images used in this study were taken intentionally and included in MATLAB. Then the test images are converted into intensity images or gray images and gray values are displayed in the histogram to determine the edge type of the images. Image noise is obtained by generating Gaussian noise in the image.

The population in this study were grade 7 th, grade 8th, and grade 9th students of SMP Negeri Urumb as many as 625 , sampling using stratified random 103 grade 7 th, 120 grade 8 th and 20 grade 9 th.

Data collection techniques in this study were questionnaires to obtain student learning style data and documentation to obtain data on student mathematics learning outcomes, mathematics learning outcomes in this study, namely the semester 1 / odd school year academic report grades of 2017/2018. The learning style questionnaire contains 33 statements, divided into three groups of statements that show the tendency of learning styles, namely 11 statements of the visual learning style group, 11 statements of the auditory learning style group, and 11 statements of the kinesthetic learning style group. Each statement has a choice of answers, namely: "Yes" given a score of 1 , and "No" is given a score of 0 . Withdrawal conclusions the tendency of learning styles is done by comparing the three values of each group learning style statement that has been filled by the subject. Drawing conclusions is based on:

If there is the highest value in a group of learning style statements, then it is concluded that subjects tend to be dominant in the learning style. (a) If there is the same highest value of the two groups of learning style statements, then the subject is classified as "the two learning styles". (b) If there is the same highest value of the three groups of learning style statements, then the subject is classified as "the three learning styles". So, it can be known what learning styles students have in the SMP Negeri Urumb Merauke.

The data processing of students 'mathematics learning outcomes begins by calculating the average acquisition results of students' end-semester tests, then dividing them into several groups according to the guidelines for the predicate interval table based on the KKM. Based on the acquisition of mathematics learning outcomes, students are then grouped in very good, good, sufficient, and need guidance. Because each class level uses a different KKM, groupings are also adjusted to the KKM used at the class level in each school.

After obtaining the results of data analysis of learning styles and mathematics learning outcomes, then the entire data will be recapitulated, to obtain data (a) Visual learning style with predicate A (very good), B (good), C (sufficient), and D (need guidance). (b) Auditing learning style with predicate A (very good), B (good), C (sufficient), and D (need guidance). (c) Kinesthetic learning styles with predicate A (very good), B (good), C (sufficient), and D (need guidance). So, it can be seen the average student mathematics learning outcomes of each learning style in each school based on KKM.

Inferential statistics Eta test correlation coefficients are used to determine whether or not the influence of learning styles on student mathematics learning outcomes, with the ETA test formula as follows [16]

$\eta=\sqrt{1-\frac{\sum Y_{T}^{2}-\left(n_{1}\right)\left(Y_{1}\right)^{2}-\left(n_{2}\right)\left(Y_{2}\right)^{2}}{\sum Y_{T}^{2}-\left(n_{1}+n_{2}\right)\left(Y_{T}\right)^{2}}}$

The basis for drawing conclusions is as follows: If the significance value is there is the influence of learning styles on the learning outcomes of mathematics. If the significance value is there is no effect of learning styles on the learning outcomes of mathematics.

\section{RESUlT AND DisCUSSION}

\section{A. Result}

The results of grouping students based on learning styles at grade 7th SMP Negeri Urumb are presented in the following table. 
TABLE I. DISTRIBUTION OF STUDENTS IN EACH LEARNING STYLE AT GRADE 7TH SMP NEGERI URUMB

\begin{tabular}{|c|c|c|c|c|}
\hline \multirow{2}{*}{ Class } & \multicolumn{3}{|c|}{ Learning Style } & \multirow{2}{*}{$\begin{array}{c}\text { Sum } \\
\end{array}$} \\
\cline { 2 - 4 } & V & A & K & (People) \\
\hline VII & 12 & 30 & 13 & 55 \\
\hline VIII & 8 & 28 & 12 & 48 \\
\hline Sum & 20 & 58 & 25 & 103 \\
\hline
\end{tabular}

In table 1 , it is known that the most learning styles possessed by students in grade 7th SMP Negeri Urumb are auditorial learning styles which are as many as 58 students with a difference of 38 students more than the visual learning style with at least 20 students, while students with kinesthetic learning styles are 25 students. The results of grouping students based on learning styles in grade 8th SMP Negeri Urumb are presented in the following table.

TABLE II. DISTRIBUTION OF STUDENTS IN EACH LEARNING STYLE AT GRADE 8TH SMP NEGERI URUMB

\begin{tabular}{|c|c|c|c|c|}
\hline \multirow{2}{*}{ Class } & \multicolumn{3}{|c|}{ Learning Style } & \multirow{2}{*}{$\begin{array}{c}\text { Sum } \\
\text { (People) }\end{array}$} \\
\cline { 2 - 4 } & V & A & K & 72 \\
\hline VII & 25 & 31 & 16 & 48 \\
\hline VIII & 11 & 29 & 8 & 120 \\
\hline Sum & 36 & 60 & 24 & \\
\hline
\end{tabular}

In table 2 it is known that $50 \%$ of the total number of students in grade 8th SMP Negeri Urumb has an auditory learning style, while $50 \%$ of other students are divided into groups of students with visual learning styles and kinesthetic learning styles. The results of grouping students based on learning styles at grade 9th SMP Negeri Urumb presented in the following table.

TABLE III. DISTRIBUTION OF STUDENTS IN EACH LEARNING STYLE AT GRADE $9^{\mathrm{TH}}$ SMP NEGERI URUMB

\begin{tabular}{|c|c|c|c|c|}
\hline \multirow{2}{*}{ Class } & \multicolumn{3}{|c|}{ Learning Style } & \multirow{2}{*}{$\begin{array}{c}\text { Sum } \\
\text { (People) }\end{array}$} \\
\cline { 2 - 4 } & V & A & K & 11 \\
\hline VII & 2 & 5 & 4 & 11 \\
\hline VIII & 2 & 7 & 2 & 22 \\
\hline Sum & 4 & 12 & 6 & \\
\hline
\end{tabular}

Based on table 3, it is known that in contrast to students in grade 9th SMP Negeri Urumb, the learning styles with the fewest students in grade 9th SMP Negeri Urumb are visual, namely only 4 out of 22 students, half of all students have a tendency toward auditory learning styles. In general, the grouping of students based on their learning styles at the SMP Negeri Urumb of Merauke is presented in the following table.

TABLE IV. DISTRIBUTION OF STUDENTS IN EACH LEARNING STYLE

\begin{tabular}{|c|c|c|}
\hline Learning Style & Sum (People) & Percentase (\%) \\
\hline Visual & 60 & 24.49 \\
\hline Auditorial & 130 & 53.06 \\
\hline Kinesthetic & 55 & 22.45 \\
\hline Sum & 245 & 100 \\
\hline
\end{tabular}

Based on table 4, it is known that the learning styles most possessed by students in the SMP Negeri Urumb in Merauke are auditory learning styles, namely as many as 130 students, as well as from each school, auditory learning styles are the most owned by students.

The results of the data analysis of learning styles and learning outcomes of mathematics, it is known that there is a difference between the learning outcomes of mathematics for each learning style of students in SMP Negeri Urumb 2017/2018 academic year, these differences include differences in the average mathematics learning outcomes for each learning style and differences in the mathematics learning outcomes of each student.

Comparison of the acquisition of mathematics learning outcomes with predicate is very good, good, sufficient and need guidance on each learning style presented in the following diagram.

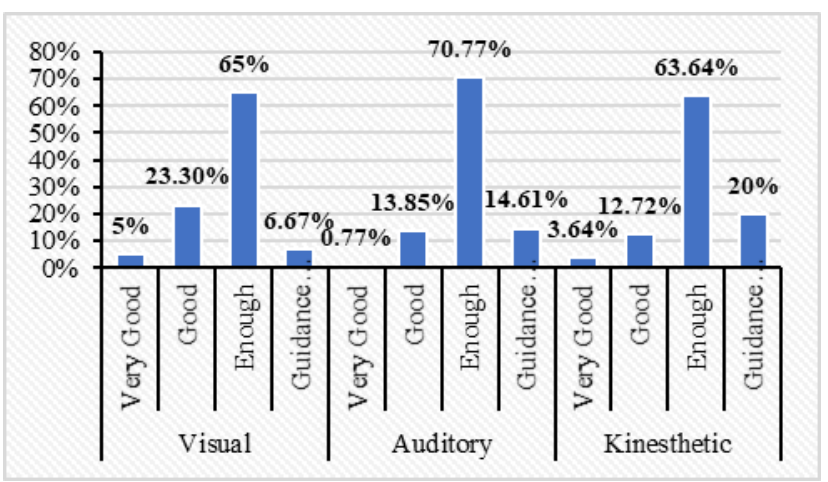

Fig. 1. Comparison diagram of mathematics learning outcomes.

From the diagram it is known that the difference in the number of students in terms of the learning outcomes of mathematics for each learning style is as follows: (1) In the visual learning style of $5 \%$ of the total number of students getting the title A (Very Good) or only $1.67 \%$ at a lower level than the number of students with the D title (Need Guidance), while most students have a visual learning style. mathematics with the title $\mathrm{C}$ (Enough). (2) As much as $0.77 \%$ of students with auditory learning styles obtain mathematics learning outcomes with predicate A (Very Good), for the number of students with the title D (Guidance Required) $0.76 \%$ greater than the number of students who are predicate B (Good), whereas $70.77 \%$ obtained the predicate (Enough). (3) $3.64 \%$ of students with kinesthetic learning styles obtain mathematics learning outcomes with predicate A (Very Good), at $13.85 \%$ with the title B (Good), at $20 \%$ with the predicate D (Need Guidance), while for 63 , $64 \%$ received the $\mathrm{C}$ (Enough) predicate.

From the description above it is known that from the overall learning style, the predicate $\mathrm{C}$ (Enough) is the one most obtained by students in the SMP Negeri Urumb. The test statistic used in this study is regression analysis with the ETA test, to determine whether or not there is an effect of learning styles on student learning outcomes in SMP Negeri Urumb throughout the City of Merauke 2017/2018 Academic Year. Then to find out the significance of the effect of learning styles on mathematics learning outcomes, the $\mathrm{F}$ test. Data analysis using the help of SPSS 23 application, with the results of the analysis presented in the following table. 
TABLE V. ETA AND F TEST RESULTS

\begin{tabular}{|c|c|c|c|}
\hline F & Sig & R & $\begin{array}{c}\text { Adjusted R } \\
\text { Squares }\end{array}$ \\
\hline 38.696 & 0.000 & 0.371 & 0.134 \\
\hline
\end{tabular}

From table 5 , the significance value is 0.00 or $<0.05$. So that it can be concluded rejecting $\mathrm{Ha}$ and accepting $\mathrm{H} 0$ means that there is an influence of learning styles on the mathematics learning outcomes of students in SMP Negeri Urumb throughout the City of Merauke 2017/2018 Academic Year. From table 5, it is known that the Adjusted $\mathrm{R}$ Square value is 0.134 which if multiplied by $100 \%$ is obtained by the value of $13.4 \%$. So that simultaneously learning styles have an effect of $13.4 \%$ on learning outcomes in mathematics.

\section{B. Discussion}

Based on the results of the learning style questionnaire analysis and mathematics learning outcomes of students SMP Negeri Urumb in Merauke City, it is known that students' learning styles are diverse, namely visual, auditory and kinesthetic learning styles, besides there are differences in student mathematics learning outcomes for each learning style. The difference is seen from the average overall mathematics learning outcomes ranging from the highest to the lowest average, also on the acquisition of student titles based on KKM. As for the results of inferential statistical analysis using a dummy variable regression test, it is known that there is an influence of learning styles on students' mathematics learning outcomes in the SMP Negeri Urumb throughout the City of Merauke. In this study the mathematics learning outcomes in question are the student's final semester test scores (grades report) of the cognitive domain.

\section{1) Learning style}

Based on the results of the learning style lift analysis, it is known that the three types of learning styles are owned by students of SMP Negeri Urumb in Merauke City, the differences in learning styles in students are supported by DePorter and Hernacki stating that each student or use different ways to understand the same information or lessons. That is, in each school each student learns in a different way, even when they study the material with the same teacher and class [4].

Every student has characteristics in learning that show their learning style, students with visual learning styles are easier to learn or receive new information by using their sense of sight, namely the eyes, for example learning from illustrated textbooks, or looking at diagrams. Students with auditory learning styles are easier to learn or receive new information with the auditory sense that is the ear, so that students can learn well if new information is obtained in the form of music, lectures or oral instructions from others. Whereas students with kinesthetic learning styles are easier to learn or receive new information through the sense of taste or by experiencing for themselves what students are learning, students can learn well through direct approaches such as in practice or other physical activities.

In this study, it was found several students with a very small difference in questionnaire filling scores between the two types of learning styles, which means that when students learn shows a tendency of more than one learning style, this is supported by the opinion of Rita Dunn [4] which states that students can use all three learning styles at once, but at a certain stage students will be more inclined to one of them. From the results of the learning style questionnaire analysis, it was found out of 245 students in the Islamic Foundation Middle School in Merauke City, there were 130 students having auditory learning styles, 60 students with visual learning styles, while the kinesthetic learning styles were slightly lower at 55 students. So it can be concluded that the dominant learning style is owned by students of SMP Negeri Urumb throughout the City of Merauke is an auditory learning style.

\section{2) Learning outcomes}

Based on the results of the analysis, it is known that in addition to learning styles, students SMP Negeri Urumb throughout the city of Merauke also obtain mathematical learning outcomes that vary from the highest to the lowest in accordance with predetermined KKM, in addition to each student's mathematics learning outcomes. The differences were also found in the average mathematics learning outcomes for each learning style group. The results of this study are more or less similar to the results of previous studies conducted with the results of research showing that the average SMP in Soppeng District had a visual learning style with the acquisition of student mathematics learning outcomes in the moderate category [17]. Besides the research, the results of the analysis are also supported by the opinion of daryanto which states that learning styles are one of the indicators that affect student learning outcomes, from the results of the analysis that most students from the overall learning style get $\mathrm{C}$ (sufficient) 166 students and only 6 students obtained learning outcomes with predicate A (very good) [14].

\section{3) Effect of learning styles on student mathematics} learning outcomes

From the results of the descriptive analysis it is known that there is an influence of learning styles on the mathematics learning outcomes of students in SMP Negeri Urumb throughout the City of Merauke in terms of the average student mathematics learning outcomes. This is supported by previous research conducted with the results of the study, namely the influence of learning styles on students' mathematics learning outcomes [17]. The results of inferential analysis show that the influence of learning styles on student mathematics learning outcomes is $13.4 \%$ and the other $86.6 \%$ is influenced by other factors. The results of this study are also supported by the opinion of Daryanto which states that in addition to learning styles, student mathematics learning outcomes are also influenced by students' backgrounds such as IQ, facilities and learning (good design, interesting offerings and fair evaluation) [14]. Students who are able to recognize and maximize their learning styles, as well as using learning strategies that are appropriate to their learning styles, will likely obtain higher mathematics learning outcomes compared to students who receive information or learn to use strategies that are not in accordance with their learning styles. In other words, if the influence given by the learning style on students' mathematics learning outcomes is greater, the mathematics learning outcomes will also be higher, this is also if it is supported by appropriate learning methods, facilities and infrastructure and other influencing factors. In the learning process it is important for teachers to recognize student learning styles, so that teachers can determine the methods and learning techniques that are suitable for use in an effort 
to achieve learning goals. Conformity of the application of learning methods and techniques by the teacher to the learning style of students in the classroom, then impacts on student learning outcomes which in this study are specifically the results of student mathematics learning in the cognitive domain.

\section{CONCLUSION}

Based on the research objectives and the results and discussion the following conclusions are obtained (1) Students in Merauke State Junior High School have different learning styles, $24.49 \%$ have visual learning styles, $53.06 \%$ have auditory learning styles, and $22.45 \%$ have kinesthetic learning styles. (2) There is an influence of learning styles on student mathematics learning outcomes in SMP Negeri Urumb Merauke.

\section{ACKNOWLEDGMENT}

Thanks to the principal of Urumb Junior High School who has given permission to research and students who help in research.

\section{REFERENCES}

[1] M. Yusuf, Metode Penelitian Kuantitatif, Kualitatif, dan Penelitian Gabungan. Jakarta: Kencana, 2017.

[2] M. Palobo, "Analysis of Teachers ' Difficulties on Developing Curriculum 2013 Lesson Plans," in 1st International Conference on Social Sciences (ICSS 2018), 2018, vol. 226, pp. 1319-1324.

[3] S. Suryabrata, Psikologi Pendidikan. Jakarta: Rajagrafindo Persada, 2007.

[4] B. DePorter and M. Hernacki, Quantum Learning: Membiasakan Belajar nyaman dan Menyenangkan. Bandung: Kaifa, 2015.

[5] Y. Tembang, M. Palobo, A. K. Hermansyah, and L. A. Prihandoko, "Improving science learning outcomes in material changes in natural appearance," IOP Conf. Ser. Earth Environ. Sci., vol. 343, no. 1, p. 012240, 2019.

[6] B. R. Werang, "Belajar dan Pembelajaran," Jakarta: Elang Emas, 2011.

[7] Sari and A. Kartika, "Analisis Karakteristik Gaya Belajar Vak(Visual, Auditorial, Kinestetik)," Univ. Trunojoyo Madura. Bangkalan, 2014.

[8] Mahmud, Psikologi Pendidikan. Bandung: Pustaka Setia, 2012.

[9] S. R. Eka, M. Palobo, Nurhayati, and M. Riyana, "Penerapan Pendekatan Scientific Dengan Model Problem Based Learning Untuk Meningkatkan Sikap Dan Prestasi Belajar Matematika Siswa Smp Negeri 9 Merauke," Magistra, vol. 5, no. 1, pp. 1525, 2018.

[10] W. . Cockcroft, Mathematics Counts. London: HMSO, 1986.

[11] S. Pajar, Pembelajaran Matematika: Cara Meningkatkan Kemampuan Berpikir Siswa. Yogyakarta: Graha Ilmu, 2014.

[12] Z. Amir and Risnawati, Psikologi Pembelajaran Matematika. Yogyakarta: Aswaja Pressindo, 2016.

[13] Slameto, Belajar dan Faktor-faktor yang mempengaruhinya. Jakarta: PT Rineka Cipta, 2013.

[14] Daryanto, Inovasi Pembelajaran Efektif. Bandung: Yrama Widya, 2013.

[15] Darmadi, Pengembangan Model dan Metode Pembelajaran Dalam Dinamika Belajar siswa. Yogyakarta: Deepublish, 2017.

[16] S. K. Asnawi and C. Wijaya, Riset Keuangan Pengujianpengujian Empiris. Jakarta: Gramedia, 2015.

[17] A. Anas and N. . Munir, "Pengaruh Gaya Belajar VAK Terhadap Hasil Belajar Matematika Siswa Kelas VII SMP Negeri di Kabupaten Soppeng Tahun Pelajaran 2013/2014,” 2014. 